\title{
북한이탈주민의 CBS 긴급재난문자 이해도 분석연구 Analysis of Degree of Understanding for CBS Alerting Texts of North Korean Defectors
}

\author{
김성수* . 주진걸** \\ Kim, Sungsoo*, and Joo, Jingul**
}

\begin{abstract}
CBS are widely used to provide information to a large number of residents in emergency situations. Although texts of CBS consists of simple and easy sentences, foreigners and North Korean defectors may not understand properly. In this study, 28 CBS standardized alerting texts were shown to North Korean defectors and the degree of understanding was measured on 5-Likert Scale. Although North Korean defectors who lived in South Korea for more than 10 years correctly understood most of the texts, defectors who lived for less than five years had difficulty in understanding the vocabulary including Chinese and other foreign words. In addition, the North Korean defectors with a longer residence period in South Korea believed that potential future North Korean defectors would be able to understand the standard text better. This shows that the degree of understanding of the standard text can be lower than the expectations of the CBS staff in case of North Korean defectors. The results of this study are expected to be applied to the propagation system of emergency disaster situations.
\end{abstract}

Key words : Cell Broadcasting Service, North Korean Defector, Emergency Disaster Situation, Standardized Alerting Text

\section{요 지}

긴급재난상황시 다수의 주민들에게 신속하게 정보를 전달하기 위하여 CBS 재난문자방송이 널리 활용되고 있다. CBS 재난문자방 송은 간략하고 쉬운 문장으로 구성되어있으나, 외국인 및 북한이탈주민은 적절하게 이해할 수 없는 경우도 있다. 이에 본 연구에서는 북한이탈주민에게 28 개의 $\mathrm{CBS}$ 표준문안을 보여주고, 이해도를 5 점 척도로 측정하였다. 남한에 10 년 이상 거주한 북한이탈주민은 대부분의 문안을 정확하게 이해하였으나, 5년 미만 거주한 북한이탈주민은 한자어와 외래어가 포함된 어휘의 이해를 곤란해 하였다. 또한, 남한 거주 기간이 긴 북한이탈주민일수록 잠재적인 미래의 북한이탈주민이 표준문안을 잘 이해할 수 있을 것으로 판단하였다. 이는 실제 북한이탈주민의 경우 표준문안 이해정도가 CBS 담당자의 기대치보다 낮을 수 있음을 보여준다. 본 연구결과는 긴급 재난상황의 전파체계에 활용될 수 있을 것으로 기대된다.

핵심용어 : 재난문자방송서비스, 북한이탈주민, 긴급재난상황, 표준문안

\section{1. 서 론}

긴급재난상황 발생시 사전에 상황을 정확하게 인지하는 것만으로도 피해를 대폭 줄일 수 있다. 이에 행정안전부, 지방자치단체 및 기상청은 폭우, 대설, 폭풍, 해일, 폭염, 지진 등의 기상특보시 긴급재난문자를 통해 관련 정보를
국민들에게 제공하고 있다. 국가비상사태 발령시나 민방공 상황정보와 방사성물질 유출 등의 긴급상황도 휴대폰을 통해 확인할 수 있다. 긴급상황 발생 또는 발생 예상지역에 전달되는 긴급재난문자는 2013년 이후 제조된 모든 휴대폰 에서 CBS(Cell Broadcasting Service) 재난문자방송기능으 로 모든 시민이 무료로 이용할 수 있다. CBS 재난문자방송

\footnotetext{
*정회원, 동신대학교 언어치료학과 교수(E-mail: sskim@dsu.ac.kr)

Member, Professor, Department of Logopedics, Dongshin University

**교신저자, 정회원, 동신대학교 토목공학과 교수(Tel: +82-61-330-3137, Fax: +82-61-330-3138, E-mail: jgjoo@dsu.ac.kr)

Corresponding Author, Member, Assistant Professor, Department of Civil Engineering, Dongshin University
} 
은 국민들에게 실시간으로 재난관련 정보를 전달하고 상황 에 맞는 대비 및 조치를 취하도록 도와주는 역할을 하여, 재난으로 인한 인적 물적 피해를 저감하는데 큰 도움을 주고 있다.

CBS 재난문자방송의 문구들은 대한민국 국민이라면 누 구나 이해하기 쉬운 문안들로 구성되어 있다. 재난관련 정보 를 글로 전달한다는 한계가 있으나, 우리나라는 문맹율이 매우 낮아 정보의 전달에 큰 문제가 없는 것으로 나타나고 있다. 그러나 외국인, 그리고 우리나라와 같은 언어를 사용하 고 있기는 하지만 상호간에 이질적인 언어 표현이 존재하는 북한이탈주민(Sung, 2007) 등 우리 글과 말이 서툰 사람들에 게는 정보전달에 한계가 있을 수 있으며, 특히 긴박한 순간에 는 신속한 정보전달이 곤란할 수도 있다.

특히 최근에는 우리나라로 유입되는 북한이탈주민의 숫 자가 급격하게 늘고 있는 실정이다. 한해 10 명 이내에 불과했 던 북한이탈주민은 김일성의 사망 이후 꾸준하게 증가하고 있어, 2000년대 후반 이후에는 연간 2,000 3,000명에 달하 고 있다. 2014년 10월 말 현재 국내 체류 중인 북한이탈주민 의 숫자는 약 27,253 명에 이르는 것으로 집계되고 있다 (Ministry of Unification, 2014). 북한이탈주민의 적응 및 정착을 위해 북한이탈주민정착사무소(하나원)과 전국 지역 적응센터(하나센터)에서 교육을 진행하고 있으나, 남북한 간의 언어차이로 인하여 의사소통에 문제가 발생하고 있다 (Kang, 2010; Moon, 2007; Lee, 2003).

$\operatorname{Kim}(2005)$, Lee(2006), Jung(2002) 등은 언어실태 조사를 통하여 북한이탈주민이 겪는 언어 적응문제를 보고하고 있으며, Park(2002), Choi(1999) 등은 북한이탈주민의 한국 어 의사소통에서의 어려움을 지적하고 있다. 또한, 남북한 언어 간의 이질화 수준에 대한 다양한 연구 결과도 제시되고 있다(Sung, 2007; Seong, 1992; Yook, 1996; Yoon, 2012).

남북한의 언어 차이로 인한 의사소통의 어려움은 재난의 전파 및 대비측면에서도 문제를 발생시킬 수 있다. 특히 긴급재난 문자의 속성상 짧고 간결한 표현으로 이루어져 있어, 북한이탈주민이 긴급 재난방송 및 긴급재난문자를 듣거나 보고, 문구나 의미를 쉽게 이해하지 못해 대피 및 조치가 늦어질 수 있다. 재난문자를 통한 재난관련 정보의 정확한 전달 여부가 추후 발생하는 인적 - 물적 피해의 정도 에 영향을 미칠 수 있다. 이에 본 연구에서는 북한이탈주민을 대상으로 설문을 수행하여 행정안전부에서 발송하는 긴급재 난문자를 얼마나 정확하게 이해하고 있는지를 분석하였다.

\section{2. 남북한 언어 차이와 북한이탈주민 교육 현황}

\section{1 남북한 언어 이질화의 배경과 원인}

남북한은 사회체제의 문제로 서로 접촉하지 못함으로 써 언어가 서로 다른 방향으로 발달하였다. 또한 남북한은
분단 이후 서로 다른 언어정책을 가지고 각기 다른 공용어 를 사용해 왔다. 북한의 표준어는 문화어(文化語)라 칭하 며, '평양말을 중심으로 한 노동 계급의 이상과 생활 감정 에 맞도록 규범화한 말'로 정의한다(한국민족문화대백과, http:/encykorea.aks.ac.kr/). 문화어를 제정하고 북한의 표준어 로 발전시키기 위해 1960년대 후반 문화어 운동이 시작되었다. 신속한 문맹 퇴치를 목적으로 문화어 운동에서는 문화어에서 한자어를 배제하였으며, 이러한 어휘정리는 분단으로 시작된 남북한 언어의 이질화를 더욱 가속화하였다(Choi, 1999).

미국 등 서방세계의 문화를 받아들인 남한은 급격한 사회 변화와 경제 발전 및 외래어의 남용으로 신조어가 출몰하고 언어가 급변했으며, 북한은 '김일성 주체사상'에 부합하는 방향으로 언어를 개조하여 말씨가 거칠며 전투적인 인상을 주도록 변화하였다(Yoon, 2012). 정치적 분단으로 인한 언어 의 분리와 더불어 이러한 사회, 문화, 정치적 요인들 때문에 현재 남북한의 언어 사이에는 서로 다른 어휘가 존재하며, 같은 단어에서도 많은 의미차이가 존재한다.

\section{2 북한이탈주민을 위한 언어교육 현황}

국내에 입국한 북한이탈주민은 북한이탈주민정착지원사 무소(하나원)에서 12 주(총 420시간)간 대한민국 시민으로서 기초소양 교육을 받는다. 하나원 기초 교육 수료이후 자신의 거주 지역의 지역적응센터(하나센터)에서 4주간 초기 집중교 육을 받으며, 이때 간단한 남북한 언어 및 발음차이 등을 배우게 된다. 하나센터 언어교육 프로그램은 2 단계로 나뉘어 져 있으며, 1 단계에서는 발음교정, 기초적인 단어 및 문장 다양한 표현과 일상생활에 필요한 표준어교육 등을 수행한다. 2단계에서는 보다 구체적이고 폭넓은 의사소통 가능한 수준 의 교육을 수행한다(Ministry of Unification, 2014). 북한이탈 주민들을 위한 남한 사회 언어적 적응을 위한 준비는 이들의 사회정착에 매우 중요한 변인임에도 불구하고, 실질적으로 이들에게 제공되고 있는 언어 교육은 그 내용 및 방식 모두에서 형식적인 것에 그치고 있는 실정이다(Lee, 2015).

\section{3. 연구방법 및 대상}

본 연구는 휴대폰 재난문자방송 표준문안 28개를 북한이 탈주민에게 보여주고, 이해정도를 설문을 통해 확인하였다. 설문대상은 남한에 입국한지 일정시간 이상의 시간이 흘러 비교적 남한의 언어를 쉽게 이해할 수 있는 대상으로 선정하 였다. Jung(2002)은 북한이탈주민이 남북한 간의 언어 차이 를 심각하게 느끼지 않게 되기까지 1년 이상의 시간이 걸리는 것으로 분석하였으며, Liu and Schneider(2001)는 18개월 이내에는 북한이탈주민이 남한의 언어에 민감한 시기로 판단한 바 있다. 이에 본 연구에서는 하나원 교육을 수료한지 3 년이 넘은 북한이탈주민을 설문 대상으로 선정하였다. 북 한이탈주민 지원센터의 도움을 받는 북한이탈주민을 대상 
으로 설문을 수행하여, 지원센터 방문 및 노출을 꺼리는 남성의 설문 숫자가 적었다. 총 19 명의 북한이탈주민으로부 터 자료를 수집하였으며, 설문대상자는 평균적으로 32.4세 에 입국하여 7.9 년간 남한에 거주한 40.3 세의 여성이다. 설문 대상자의 성별, 연령, 탈북 후 대한민국 입국 후 체류기 간 등의 기초정보는 Table 1 과 같다.
행정안전부, 홍수통제소, 기상청, 환경부, 보건복지부 질 병관리본부, 경찰청, 원자력안전위원회 등에서 $\mathrm{CBS}$ 를 통해 주민에게 발송되는 문자의 표준문안 28 개를 설문대상자에 게 공개한 후 이해정도를 5점 척도로 묻는 방식으로 설문을 진행하였다. Table 2는 설문 대상자에게 제시된 28 개의 CBS 의 재난공지를 위한 표준문안이다.

Table 1. Background Information of Participants

\begin{tabular}{|c|c|c|c|}
\hline Characteristics & \multicolumn{2}{|c|}{ Participants (Number) } & Mean \\
\hline \multirow{2}{*}{ Gender } & Male & 1 & \multirow{2}{*}{-} \\
\hline & Female & 18 & \\
\hline \multirow{3}{*}{ Stay Duration(yr) } & $3 \sim 5$ & 8 & \multirow{3}{*}{$7.9 \mathrm{yr}$} \\
\hline & $6 \sim 10$ & 7 & \\
\hline & $11 \sim 15$ & 4 & \\
\hline \multirow{3}{*}{ Age } & $20 \sim 30$ & 8 & \multirow{3}{*}{ 40.3(yrs old) } \\
\hline & 40 & 9 & \\
\hline & 50 & 2 & \\
\hline
\end{tabular}

Table 2. Standardized Alerting Expressions of CBS

\begin{tabular}{|c|c|}
\hline Items & Standardized Alerting Expressions \\
\hline 태풍주의보 & $\begin{array}{l}\bigcirc \bigcirc \text { 일 } \bigcirc \text { 시 } \bigcirc \bigcirc \text { 지역 태풍주의보, 강풍 및 폭우가 예상되니 시설물 결속, 해안가 접근금지 } \\
\text { 등 피해 없도록 대비하세요. }\end{array}$ \\
\hline 태풍경보 & $\begin{array}{l}\bigcirc \bigcirc \text { 일 } \bigcirc \bigcirc \text { 시 } \bigcirc \bigcirc \text { 지역 태풍경보, 해안지대 접근금지, 선박대피, 농수산물 보호행위 자제 등 } \\
\text { 피해 없게 주의하세요. }\end{array}$ \\
\hline 호우경보 & $\begin{array}{l}\bigcirc \bigcirc \text { 일 } \bigcirc \text { 시 } \bigcirc \text { 지역 호우경보, 상습침수지역 대피, 위험지역 통제농작물 보호행위 자제 등 } \\
\text { 안전에 주의하세요. }\end{array}$ \\
\hline 홍수주의보 & $\bigcirc \bigcirc$ 월 $\bigcirc$ 일 $\bigcirc \bigcirc: \bigcirc \bigcirc \bigcirc$ 강(천) $\bigcirc \bigcirc$ 지점 홍수주의보 발령, 안전에 유의하시기 바랍니다. \\
\hline 홍수경보 & $\begin{array}{l}\bigcirc \bigcirc \bigcirc \bigcirc \bigcirc \bigcirc \bigcirc \bigcirc \bigcirc \text { 강(천) } \bigcirc \bigcirc \text { 지점 홍수경보 발령, 추가 대피령 발령 시 대피하시기 바 } \\
\text { 랍니다. }\end{array}$ \\
\hline 대설경보 & $\begin{array}{l}\bigcirc \bigcirc \text { 일 } \bigcirc \text { 시 } \bigcirc \bigcirc \text { 지역 대설경보, 대중교통이용, 비닐하우스 눈 제거, 내집앞 눈치우기, 눈길 } \\
\text { 미끄럼 등 조심하세요. }\end{array}$ \\
\hline $\begin{array}{l}\text { 폭풍해일 } \\
\text { 주의보 }\end{array}$ & $\begin{array}{l}\bigcirc \bigcirc \text { 일 } \bigcirc \text { 시 } \bigcirc \text { 지역 해일주의보, 해안저지대 주민들께서는 비상휴대품을 준비, 대피 권고 } \\
\text { 시 신속히 대피바랍니다. }\end{array}$ \\
\hline $\begin{array}{l}\text { 폭풍해일 } \\
\text { 경보 }\end{array}$ & $\begin{array}{l}\bigcirc \bigcirc \text { 일 } \bigcirc \text { 시 } \bigcirc \text { 지역 해일경보, 해안저지대 주민들께서는 즉시 높은 지역이나 튼튼한 건물 } \\
\text { 등으로 대피바랍니다. }\end{array}$ \\
\hline $\begin{array}{l}\text { 지진해일 } \\
\text { 주의보 }\end{array}$ & $\begin{array}{l}\bigcirc \bigcirc \text { 일 } \bigcirc \text { 시 } \bigcirc \text { 지역 지진해일주의보, 선박대피, 해변저지대 주민은 높은 곳이나 튼튼한 건 } \\
\text { 물 등으로 대피바랍니다. }\end{array}$ \\
\hline $\begin{array}{l}\text { 지진해일 } \\
\text { 경보 }\end{array}$ & $\begin{array}{l}\bigcirc \bigcirc \text { 일 } \bigcirc \text { 시 } \bigcirc \text { 지역 지진해일경보, 선박은 먼 바다 대피, 해변저지대 주민은 이웃 전파, 높 } \\
\text { 은 지대로 대피바랍니다. }\end{array}$ \\
\hline 한파경보 & $\begin{array}{l}\bigcirc \bigcirc \text { 일 } \bigcirc \text { 시 } \bigcirc \text { 지역 한파경보, 노약자 외출자제 건강유의, 동파방지, 화재예방 등 피해 없 } \\
\text { 도록 주의하세요. }\end{array}$ \\
\hline 강풍경보 & $\begin{array}{l}\bigcirc \bigcirc \text { 일 } \bigcirc \text { 시 } \bigcirc \text { 지역 강풍경보, 간판 등 부착물 고정, 선박 결박, 비닐하우스 등 시설물에 } \\
\text { 피해 없게 주의하세요. }\end{array}$ \\
\hline 풍랑경보 & $\begin{array}{l}\bigcirc \bigcirc \text { 일 } \bigcirc \text { 시 } \bigcirc \text { 지역 풍랑경보, 어선 출항 금지, 해안가 낚시.야영객은 안전지대로 대피 하 } \\
\text { 시기 바랍니다. }\end{array}$ \\
\hline 폭염주의보 & $\begin{array}{l}\bigcirc \bigcirc \text { 일 } \bigcirc \text { 시 } \bigcirc \text { 지역 폭염주의보, 노약자 야외활동 자제, 충분한 수분섭취, 물놀이 안전주의 } \\
\text { 등 건강에 유의하세요. }\end{array}$ \\
\hline
\end{tabular}


Table 2. (Continued)

\begin{tabular}{|c|c|}
\hline Items & Standardized Alerting Expressions \\
\hline 폭염경보 & $\begin{array}{l}\bigcirc \bigcirc \text { 일 } \bigcirc \text { 시 } \bigcirc \text { 지역 폭염경보, } 14 \text { 시부터 } 16 \text { 시까지 야외활동 자제와 충분한 물마시기 등 건 } \\
\text { 강에 유의하세요. }\end{array}$ \\
\hline 안개주의보 & $\begin{array}{l}\text { <내륙지역> } \\
\bigcirc \bigcirc \text { 일, } \bigcirc \bigcirc \text { 시 현재 짙은 안개 주의! 운전시 감속운행, 비상등 점멸 안전거리 유지 등 안전 } \\
\text { 사고 없도록 유의하세요. } \\
\text { <해안지역> } \\
\bigcirc \bigcirc \text { 일, } \bigcirc \bigcirc \text { 시 현재 } \bigcirc \bigcirc \text { 지역 안개주의보, 운전시 비상등 점멸, 안전거리 유지, 선박출항자제 } \\
\text { 등 안전사고 없도록 유의하세요. }\end{array}$ \\
\hline 지진 & $\begin{array}{l}\text { [기상청] } \\
\text { 오늘 } \bigcirc \bigcirc: \bigcirc \bigcirc \bigcirc \bigcirc \bigcirc \bigcirc \bigcirc \bigcirc \bigcirc \bigcirc 00 \mathrm{~km} \text { 지역 규모 } \bigcirc . \bigcirc \text { 지진 발생 / 여진 등 안전에 주 } \\
\text { 의바랍니다. }\end{array}$ \\
\hline 감염병 & $\begin{array}{l}\text { [보건복지부 질병관리본부] } \\
\text { 감염병 별 예방 특성에 맞는 문구사용 }\end{array}$ \\
\hline 미세먼지경보 & $\begin{array}{l}\text { 오늘 } \bigcirc \bigcirc \text { 시 } \bigcirc \bigcirc \text { 지역 미세먼지 경보 발령, 어린이·노약자 실외활동 금지, 야외수업 금지, } \\
\text { 마스크 착용하세요. }\end{array}$ \\
\hline $\begin{array}{l}\text { 총기 - 폭발물 테러 } \\
\text { 의심 상황 발생 }\end{array}$ & $\begin{array}{l}\text { 오늘 } \bigcirc \bigcirc \text { 시 } \bigcirc \bigcirc \text { 지역 총기난사(폭발) 상황발생, } \bigcirc \bigcirc \text { 지역 접근금지, 가까운 건물 등 안전한 } \\
\text { 장소로 대피바랍니다. }\end{array}$ \\
\hline $\begin{array}{l}\text { 기타 수단에 의한 } \\
\text { 테러 의심 상황 발생 }\end{array}$ & $\begin{array}{l}\text { 오늘 } \bigcirc \bigcirc \text { 시 } \bigcirc \bigcirc \text { 지역 } \bigcirc \bigcirc \text { 에 의한 인명피해 발생, } \bigcirc \bigcirc \text { 지역 접근금지, 가까운 건물 등 안전 } \\
\text { 한 장소로 대피바랍니다. }\end{array}$ \\
\hline $\begin{array}{l}\text { 화학사고(테러) } \\
\text { 의심 상황 발생 }\end{array}$ & 오늘 $\bigcirc \bigcirc$ 지역에 화학사고(테러) 의심 상황 \\
\hline $\begin{array}{c}\text { 생물테러 } \\
\text { 의심 상황 발생 }\end{array}$ & $\begin{array}{l}\text { 오늘 } \bigcirc \bigcirc \text { 지역 생물테러 의심 상황으로 인한 } \bigcirc \bigcirc \text { 감염병 환자발생, 외출자제, } \mathrm{TV} \text { 등 청취바 } \\
\text { 랍니다. }\end{array}$ \\
\hline $\begin{array}{l}\text { 방사성물질 누출 예상 } \\
\text { 및 상황 발생 }\end{array}$ & $\begin{array}{l}\text { [원자력안전위원회] } \\
\text { 오늘 } \bigcirc \bigcirc \text { 원전 방사선 청색(적색) 비상 발령, 외출자제, TV 등 청취바랍니다. }\end{array}$ \\
\hline 공습경보 & $\begin{array}{l}\bigcirc \bigcirc \text { 일 } \bigcirc \bigcirc \text { 시 부로 } \bigcirc \bigcirc \text { 지역 공습경보 발령, } \\
\text { 주간: 가까운 지하대피시설로 대피 후, 방송청취를 바랍니다. } \\
\text { 야간: 전등을 모두 끄고 안전한 곳으로 대피 후 방송청취를 바랍니다. }\end{array}$ \\
\hline 경계경보 & $\begin{array}{l}\bigcirc \bigcirc \text { 일 } \bigcirc \bigcirc \text { 시 부로 } \bigcirc \bigcirc \text { 지역 경계경보 발령, } \\
\text { 방송을 들으면서 행정안전부의 지시에 따라 행동하여 주시기 바랍니다. }\end{array}$ \\
\hline 화생방경보 & $\begin{array}{l}\bigcirc \bigcirc \text { 시 } \bigcirc \text { 분 } \bigcirc \bigcirc \text { 지역, 화생방경보 발령, 호흡기 및 피부 등을 보호하시고 비 오염지역으로 } \\
\text { 신속히 대피 바랍니다. }\end{array}$ \\
\hline 경보해제 & $\bigcirc \bigcirc$ 일 $\bigcirc \bigcirc$ 시 부로 $\bigcirc \bigcirc$ 지역 $\bigcirc \bigcirc$ 경보 해제, 정상업무에 임하시기 바랍니다. \\
\hline
\end{tabular}

\section{4. 설문 및 분석결과}

제시된 표준 문안에 대하여 본인의 이해정도를 '이해하기 매우 어렵다(1점)'에서부터 ‘이해하기 매우 쉽다(5점)' 까지 의 5점 척도(5-Likert Scale)로 평가하도록 하였다. 또한, 최근 에 남한에 입국하거나, 장차 입국할 잠재적인 북한이탈주민들 의 경우 표준 문안을 어느 정도 이해할 수 있을 것이라고 생각하는지를 동일한 척도로 답변하도록 하였다. Fig. 1은 체류기간에 따른 표준문안에 대한 이해도를 나타낸다. 남한에 서의 체류기간이 길수록 이해정도가 높게 나타났다. 체류기간 10 년 이상인 경우 대부분의 문안을 비교적 정확하게 이해하고 있었으며, 5년 미만인 경우 이해도가 낮게 나타났다. 5 10년 의 경우 이해도에 있어서 개인적 편차가 큰 것으로 나타났다.

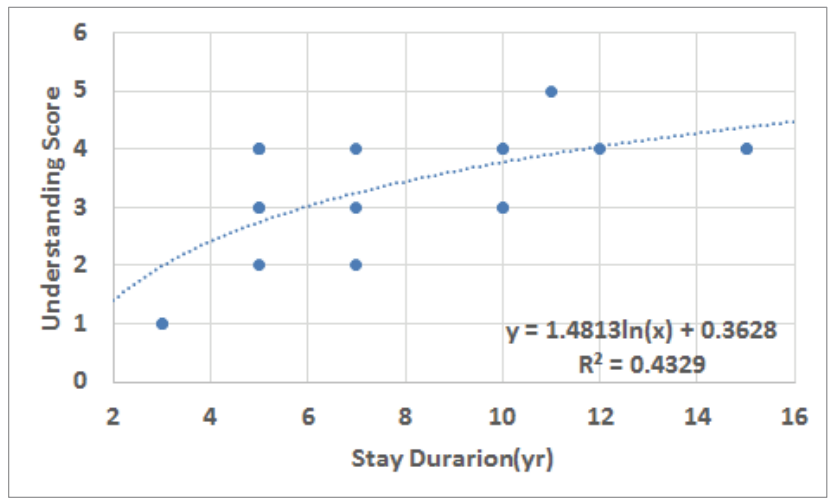

Fig. 1. The Comprehensibility of Standardized Alerting Expression by Stay Duration within South Korea 
북한이탈주민들은 향후 한국에 입국하게 될 미래의 북한 이탈주민이 자신들보다 표준문안 이해정도가 다소 낮을 것(5점 척도 중 1점만큼의 차이)으로 생각하였으며, 남한에 서의 체류기간이 길었던 대상일수록 본인과 새로 입국하게 될 미래의 북한이탈주민 간의 표준문안 이해도 격차가 클 것이라고 답하는 경향이 나타났다(Table 3). 다만, 절대적인 표준 문안 이해도에 있어서는, 한국에서의 체류시간이 길수 록 새로 입국하게 될 미래의 북한이탈주민이 잘 이해할 수 있을 것으로 판단하였다. 본인이 남한에서 오래 거주하며 쉽게 이해할 수 있는 단어나 문장을 새로운 북한이탈주민도 쉽게 이해할 수 있을 것으로 생각하였다.

연령이 높을수록 표준문안 이해도가 높은 것으로 나타났 으며(Fig. 2), 이는 남한에서의 체류기간과 현재 연령이 선형 관계에 있기 때문으로 판단된다. 입국 당시의 나이는 본인의 이해도 및 새로 입국할 북한이탈주민의 이해도 모두에 영향 을 미치지 않는 것으로 나타났다(Table 4).

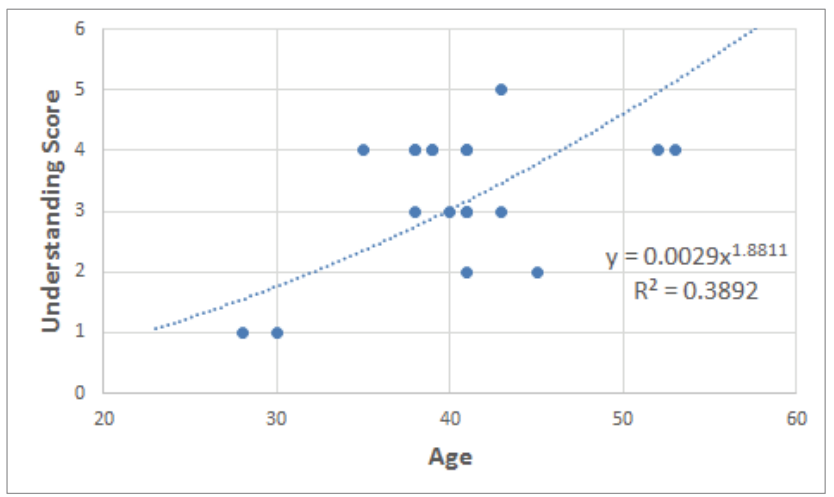

Fig. 2. The Comprehensibility of Standardized Alerting Expression by Age
표준 문안에 사용된 단어 중 북한에서 잘 사용하지 않거나, 이해하기 힘든 단어로는 해일이 가장 많이 언급되었으며(11 회), 테러(9회), 노약자, 비닐하우스, 감염병(각 6회) 등이 뒤를 이었다. 미세먼지, 휴대품(각 5 회), 폭염, 결속(각 4회) 등의 단어도 이해하기 어려운 단어 상위순위에 포함되었다. 주로 한자어나 외래어 등 특정 단어에 대한 이해를 어려워하 였으며, 문장구조 등 전반적인 의미전달에 있어서는 어려움 이 없는 것으로 나타났다.

\section{5. 결 론}

본 연구에서는 남한에 거주 중인 북한이탈주민들을 대상 으로 설문조사를 통하여 $\mathrm{CBS}$ 표준문안 이해도를 분석하였 다. 설문자 본인과 장차 입국가능성이 있는 북한이탈주민들 의 표준문안 이해도를 5 점 척도로 평가하였다. 그 결과 남한 거주기간이 5년 미만인 경우 표준문안 이해도가 낮았으며, 10 년 이상인 경우는 대부분의 내용을 쉽게 이해할 수 있는 것으로 나타났다. 북한이탈주민들 한자어 및 외래어와 최근 이슈가 되고 있는 한자어를 포함한 신조어 등의 어휘를 이해하기 곤란해 하였으며, 전반적인 문장구조 등을 이해하 는 데는 어려움이 없는 것으로 나타났다.

다만, 남한에 오래 거주할수록 잠재적 북한이탈주민들 이 표준문안을 잘 이해할 수 있을 것으로 생각하였다. 즉, 표준문안 작성 및 발송 담당자를 포함한 남한 주민들은 북한이탈주민들이 실제보다 표준문안을 잘 이해할 수 있을 것으로 생각할 것이며, 실제 북한이탈주민들은 재난 정보 의 이해도가 기대치보다 낮을 수 있다. 이는 신속하고 정확 한 재난정보의 전달에 부정적인 영향을 미칠 수 있을 것으 로 판단된다.

Table 3. The Comprehensibility of Standardized Alerting Expression of Participants and Expected Score for New North Korean Defectors by Stay Duration within South Korea

\begin{tabular}{c|c|c|c}
\hline Stay Duration(yr) & $\begin{array}{c}\text { Understanding Score for North } \\
\text { Korean defectors(A) }\end{array}$ & $\begin{array}{c}\text { Expected Understanding Score } \\
\text { for New defectors(B) }\end{array}$ & Difference(A-B) \\
\hline $3 \sim 5$ & 2.75 & 1.88 & 0.875 \\
\hline $6 \sim 10$ & 3.29 & 2.00 & 1.29 \\
\hline $11 \sim 15$ & 4.25 & 2.38 & 1.87 \\
\hline Average & 3.26 & 2.26 & 1.00 \\
\hline
\end{tabular}

Table 4. The One's Comprehensibility vs Expected Comprehensibility of New North Korean Defectors by Age at Entry into South Korea for Standardized Alerting Expression

\begin{tabular}{c|c|c}
\hline Age at entry & $\begin{array}{c}\text { Understanding Score } \\
\text { for Current Refugees }\end{array}$ & $\begin{array}{c}\text { Expected Understanding Score } \\
\text { for New Refugees }\end{array}$ \\
\hline Under 30 & 2.86 & 2.57 \\
\hline $31-35$ & 3.71 & 2.71 \\
\hline $36-40$ & 3.20 & 1.20 \\
\hline
\end{tabular}


본 연구 결과를 기초로 외국인, 북한이탈주민 등을 대상으 로 재난정보 전달방법에 따른 이해 정도에 대한 폭넓은 조사를 추가한다면, 재난정보 전달 체계에 활용할 수 있을 것으로 기대한다.

\section{감사의 글}

본 연구는 국민안전처 자연재해저감기술개발사업단(자 연피해예측및저감연구개발사업)의 지원으로 수행한 '기후 변화 적응을 위한 연안도시지역별 복합원인의 홍수 취약성 평가기술 개발 및 대응 방안 연구' [MPSS-자연-2015-77]과 제의 성과입니다.

\section{References}

Choi, H.C. (1999) A Proposal for a Unified Language in the South and the North Korea: the Language Policy. The Journal of International Korean Studies, Vol. 1, No. 1, pp. 35-85.

Jung, K.I. (2002) The Survey of the Linguistic Adaptation of the Defectors from North Korea to South Korea. The Sociolinguistic Journal of Korea, Vol. 10, No. 1, pp. 253-274.

Kang, C.K. (2010) North Korean Refugee Supporting Policy Based on Barrier Factor Analysis. The Korean Journal of Unification Affairs, Vol. 22, No. 1, pp. 261-290.

Kim, S.H. (2005) How to Perceive the Language Differentiation between the Two Koreans. Review of North Korean Studies, Vol. 8, No. 2, pp. 85-124.

Lee, H.K. (2003) A study on the University Life Experience of North Korean Defectors in South Korea. Master's thesis, Ewah Womans University.

Lee, K.S. (2006) A Study of the Social Adaptation Process of Women Migrants: Focus on North Korean Residents in South Korea. The Journal of Asian Women, Vol. 45, No. 1, pp. 191-234.

Lee, Y.K. (2015) The Phenomenological Analysis About the
Aspect of Communication of North-Korea Refugees Within South-Korea Society. Master's thesis, Dongshin University.

Liu, H.C.S. Schneider, L.J. (2001) Perceived Counselor Acculturation Levels: Their Pertinence to Caucasian Client Expectations. Paper Presented at the 109th Annual Conference of the American Psychological Association.

Ministry of Unification (2014) 2014 Unification White Paper. Moon, K.H. (2007) Education Policy to Improve Vocabulary and Communication Skills for North Korean Refugees. The Academy for Korean Language Education, Vol. 76. pp. 141-172.

Park, I.S. (2002) A Survey on the Recovery of the Identities between the South Korean Language and the North Korean Language. Master's thesis, Sunmoon University.

Seong, I.H. (1992) The Speech Community Viewed from Linguistic Heterogeneity After Unification of SouthNorth Korea. Regular Academic Conference: The Problems of the Unified Korea Nation of the Korean People, Vol. 9, pp. 165-195.

Sung, S.M. (2007) A Study on the Recovery of Homogeneity for the Increasingly Heterogeneous Language of Two Koreas: With an Emphasis on Language Policy and Linguistic Purification Process. Master's thesis, Dongguk University.

Yook, H. (1996) The Linguistic Differences between South and North Korea. Korean Education, Vol. 53, pp. 255-267.

Yoon, I.S. (2012) The Linguistic Heterogeneity of South and North Korea. Collected Papers on Christian Language Culture, Vol. 15, pp. 119-134.

\begin{tabular}{|l|l|}
\hline Received & $\begin{array}{l}\text { December 29, } 2017 \\
\text { December 29, } 2017\end{array}$ \\
\hline Revised & January 2, 2018 \\
\hline Accepted &
\end{tabular}

